This is a postprint version of the following published document:

Kallimopoulou, E. and Kornetis. K. (2017). "Magical Liturgy": A History of Sound at the Kyttaro Music Club, 1970-1974. Journal of Modern Greek Studies, (9), pp. 481-511

DOI: $10.1353 / \mathrm{mgs} .2017 .0028$

(C) 2017 by The Modern Greek Studies Association 


\title{
"Magical Liturgy": A History of Sound at the Kyttaro Music Club, 1970-1974
}

\author{
Eleni Kallimopoulou and Kostis Kornetis
}

\begin{abstract}
Kyttaro was an alternative club in the center of Athens during the Colonels' dictatorship. This article demonstrates how the affective economy and political energy of the live musical performances that took place there turned it into a vehicle of cultural and political contestation for the progressive youth of the time. It also challenges dominant periodizations in relation to the dictatorship, highlighting the continuities of cultural practices, group behavior, and youth protest. Lastly, drawing upon a range of sources, including oral testimonies with key figures in the music scene of the time, the article highlights the importance of sensorial and "from below" insights for the study of cultural phenomena.
\end{abstract}

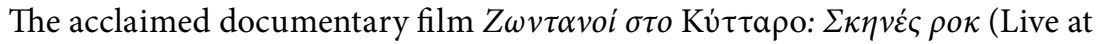
the Kyttaro: Rock scenes, 2005) kicks off with a street sequence in black and white, shot in a super-8 manner, that resembles footage from the 1970s. Rock musician and actor Dimitris Poulikakos, a signature figure of the 1960s, rides an old BMW motorcycle with a sidecar, in which is seated the much younger Antonis Boskoitis, the director of the film. Clad in Vietnam-style military jackets, they both sport long hair and beards. The camera follows them as they traverse the area of central Athens near the Kyttaro-a club created in 1970 and still running. To the sound of «Oı $\mu \eta \chi \alpha v \varepsilon \dot{\varepsilon} \varsigma$ ov» (My machines) sung by the duo Lida-Spyros (1972), the two converse in an existentialist, beatnik mood about motorcycles and the state of being on the road. Poulikakos makes a sudden stop, his attention caught by a person on the side of the street (musician Yannis "Bach" Spyropoulos) reciting poetry with Dadaist influences. Eventually, the motorbike pulls up in front of the Kyttaro. This carefully staged opening scene introduces us both to the real and the symbolic role that Kyttaro played as an urban space in the 1970 s, making the crucial bridge with the present. 
Chronologically closer to the original Kyttaro sessions of the early 1970s

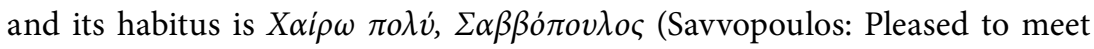
you), a documentary film and early tribute to Dionysis Savvopoulos, the Greek poète-chansonnier of the 1960s par excellence, directed by Lakis Papastathis (1976). The film offers another instance of inhabiting urban space: in a key sequence, Savvopoulos walks in the center of Athens, off Omonoia square. He is bearded, with sunglasses and a long dark coat, guitar in hand. Passers-by look at him, almost apprehensively; he seems displaced, his presence haunting.

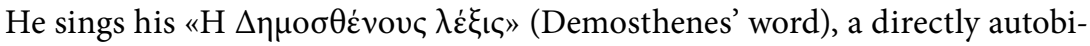
ographical and openly political song sung in first person, contemplating the feeling of total alienation that awaits a dissident's exit from prison:

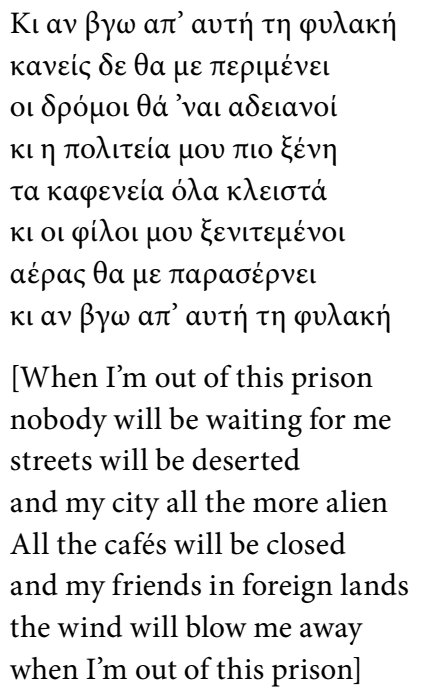

All this takes place within an urban space that had undergone a deep transformation. According to Gail Holst-Warhaft, in Savvopoulos's eyes, "Greece had become a 'hovel,' its roof leaked, the streets of Athens were full of pimps, informers, depressed youth. Savvopoulos [i]s the city's avant-garde muse" (Holst-Warhaft 2007). Savvopoulos evokes Walter Benjamin's flâneur: wandering troubadour, metropolitan-walker, at the margins, his allegorical gaze falling upon the city of the alienated man (Benjamin 1969). His figure is at once disquieting and grotesque-in fact, purposefully so. At a certain point of the film, Savvopoulos encounters his own caricatured self, somebody wearing a gigantic paper mask, a replica of his own face. As the two cross paths, Savvopoulos turns and grins at the camera (Figure 1). 


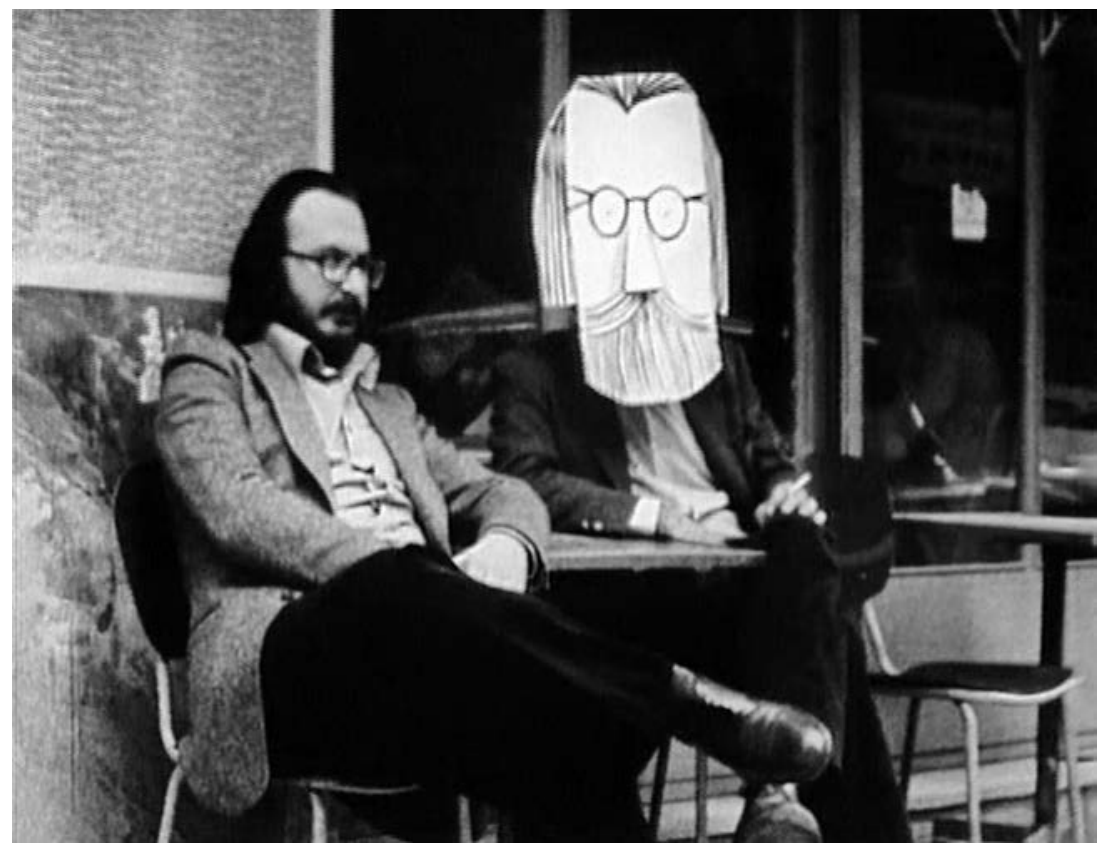

Figure 1 Dionysis Savvopoulos in Lakis Papastathis's 1976 tribute film on his career. Portrayed as a wandering troubadour, a metropolitan-walker, but also a Dylan-esque figure with a split, caricatured self, Savvopoulos represents the early habitus of the entire Kyttaro club. Source: Courtesy of Lakis Papastathis.

Besides the central role of both Poulikakos and Savvopoulos in the discussion that follows, the two scenes described above share a common theme: the inhabiting of the fragmented public space and the radical transformations in the musical topographies of youth during the years of the Colonels' dictatorship (1967-1974).

The present article focuses on a legendary moment of the music reception of youth under the authoritarianism of the dictatorship: the sessions at Kyttaro, performed in the period 1971-1974. These were events of extraordinary countercultural energy in the very middle of the regime's reign, constituting a response to the growing demand of young audiences for alternative music. Socrates' guitarist Yannis Spathas describes the shows as containing "the spirit of protest" and remembers the exhilaration of the young people present

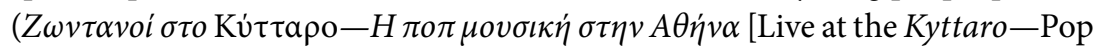
music in Athens [1971] 1996, sleeve). The music performed there was a fusion of progressive, folklorist, and acutely political elements. Dynamic representatives 
of the emerging rock scenes-such as Exadaktylos, Damon and Feidias, and Socrates-performed alongside Dionysis Savvopoulos. Greek folk tunes were mixed with psychedelia and plenty of references to the international pop scene, especially the emblematic Woodstock festival, with its merging of the political with the countercultural. ${ }^{1}$

Through a detailed description of the musical sessions that took place at Kyttaro, this article explores the intersections between the musical politics of urban youth and the sensuous experience of live performance. Our approach builds upon recent critical work that foregrounds the sensorial and affective power of cultural performance. Popular culture theorist George Lipsitz draws attention to the oppositional potential of culture $(2001,17)$ suggesting that popular music in particular has the "ability to conflate music and lived experience, to make both the past and present zones of choice that serve distinct social and political interests" $(2001,104)$. The fact that music represents "a remarkable meeting point of intimate and social realms," in the words of media and culture researcher David Hesmondhalgh $(2014,2)$, may in fact account for its heightened ability to articulate alternative as well as dominant social relations. In this vein, Lawrence Grossberg, a pioneer in the study of affect and politics in popular music, describes popular culture as "an important site of people's passion" (1992, 78), as something that is "always more than ideological," providing "sites of relaxation, privacy, pleasure, enjoyment, feeling good, fun, passion and emotion" $(1992,79)$. This suggests that any ideological work at play is first and foremost inscribed on the body.

In parallel, our analysis draws on the recent theoretical discussion on the senses, which argues for their interconnectivity and for integrated approaches of multisensoriality. In his important examination of archaeology and the senses, Yannis Hamilakis renounces the Western sensorium, with its five clearly delimited and regimented senses, as being largely a construct of modernity. Instead, he argues for the infinity of sensorial modalities that are multiple and heterogeneous, since they link different senses in countless combinations, depending on the varied contexts in which the sensorial experience occurs (Hamilakis 2013, 113-114). We argue that during the period in question Kyttaro constituted a distinct sensorial field activated by a multiplicity of sensorial flows: the combined experiences of hearing and seeing, the "hear-by-feeling" sensation generated by very low sounds (Friedner and Helmreich 2012), ${ }^{2}$ the kinaesthetic experience of moving in close proximity to other bodies, and-in the case of many members of the bands and audience-intoxication.

In this article, we approach the world of Kyttaro as a distinct multisensorial modality and ask how it affected (rather than what it represented for) the 
audience and the musicians alike. In contextualizing the history of sound and auditory culture of Kyttaro, we address the following two questions. In what ways did music offer a field for voicing protest against the junta and negotiating alternative cultural and political identities? And how were performances at Kyttaro constituted as a multisensorial and affective experience? Our study aims to foreground Kyttaro as a space of social interaction and identification, one that offered opportunities to habitués to refashion themselves and identify with others (Malbon 1998, 278).

Our discussion is based on the analysis of audio and audiovisual material-notably, the live audio recording Live at the Kyttaro and footage from the original Kyttaro performances. It is also founded on textual sources (memoires, press articles, and so on) and oral testimonies by protagonists (musicians as well as individuals involved in the filming a nd recording of these e vents). Through an emphasis on the discourse and recollections of participants, the article seeks to gain understandings "from below" (Thompson 1966; Zinn 1980), meaning from the bottom up, ${ }^{3}$ and to make inroads in the study of the memory of sound and the senses during the Colonels' junta in Greece.

\section{The politics of music during the junta}

The r egime of the Colonels placed $\mathrm{g}$ reat e mphasis on the surveillance and control of cultural production. The preemptive censorship which was imposed during the first years over the media, publishing, and visual and performing arts was lifted in 1969, a fact that greatly facilitated the rise of general radicalism in the early 1970s, paving the way for a more polyphonic expression of dissent, including the circulation of more overt political messages. Somewhat paradoxically, censorship-which persisted after 1970 despite the Colonels' "strategic tolerance" of a certain kind of public discontent (Van Steen 2015, 152) - conferred a latent political quality on artistic and cultural production during the junta. Books, songs, films, and theater plays, particularly those which complied the least with the officially sanctioned a ltural forms and ideas, were potentially political, not least because of the intention of politically engaged spectators to read them politically and discover hidden meanings between the lines. Through innuendo, allusion, metaphor, cryptic language, and other strategies of subversion, these plays, books, and films conveyed political messages to the initiated, as has been demonstrated by a number of works on the cultural politics of the period (Van Dyck 1998, 21-28; Asimakoulas 2009, 32-34; Papanikolaou 2010, 180-182; Kornetis 2013, 158-162; Papadogiannis 2015, 41-45). Modern Greek theater specialist Gonda Van Steen has also 
convincingly demonstrated how these spheres interacted and communicated, with people like Nikos Xylouris, for instance, instantly evoking the singer's role

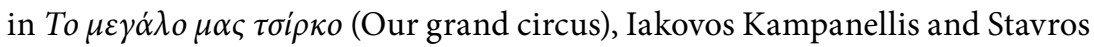
Xarchakos's signature political play of 1973, arguing that foreign dependency was Greece's eternal peril (Van Steen 2015, 189-226).

By the late 1960s, Anglo-American rock music was also taking root in Greece. Radio programs, youth music magazines, imported music records, and Rock ' $n$ ' roll movies had contributed to the formation of an increasingly distinctive local rock scene with a dedicated audience. At the time, rock music was one of two musical genres-the other being the home-grown Nío Kú $\mu \alpha$ (Neo Kyma, New Wave)-distinctively associated with and marketed for the youth. The youngsters who identified with Rock 'n' roll were pejoratively called

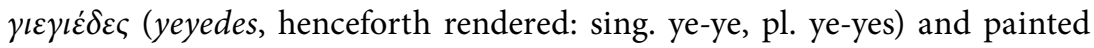
unfavorably by the press as delinquent, impudent youths who had gone astray. Filmic representations further enhanced this portrait with a buffoonish element-following perhaps the stereotypical depiction of a previous youth subculture with counterparts abroad, namely, the teddy-boys, as deviant. In reality, the older generation was alarmed by the gradual emergence of a younger one appearing to defy moral and societal norms, such as showing due respect to their family and elders. Around the world, rock was bringing about a revolution of the everyday, in terms of dress, social manners, and sexual mores. Popular music expert Andy Bennett notes how Rock 'n' roll helped forge "new cultural territories" that allowed young people to challenge their disempowered status in society and to articulate a form of everyday politics $(2005,123,125)$. In the Greek context, given the influence traditionally exerted on the young by the family, the impact of this revolution was quite intense. ${ }^{4}$ It is important to stress here that we refer to the urban context, and primarily Athens and Thessaloniki, and not the rural areas, in which ye-yes and later on hippies were still exotic figures. ${ }^{5}$

The Rolling Stones concert in April 1967, just days before the coup d'etat, at the Panathinaikos Stadium-a concert that was violently interrupted by the police when the band's manager threw to the audience some red roses, which the former interpreted as a left-wing signal-was a key event that served as a rite of initiation for many young people. Tassos Falireas, who later owned the emblematic record store Pop Eleven in Athens, appeared at the concert with Dimitris Poulikakos, a central figure in the Greek rock scene, who will be discussed later. His very vivid description captures the spirit of the time $v i s-\grave{a}$-vis the Otherness that rockers represented through their eccentric dress and raucous behavior: ${ }^{6}$ 
Of course, I went to the concert of the Stones at Panathinaikos stadium. We went with Poulikakos. I wore a fur, and he wore weird things, and as we came out of the concert and we were a bit stoned, they started to call us names. And we carried stones in such cases, and we threw them at them, and they answered back. (Falireas 2011)

However, Rock 'n' roll also carried the seeds of political radicalization. Despite being largely represented as apolitical-especially by the Greek Left (Katsapis 2007,298 ) - the ways of listening to and performing rock music were far from homogeneous, ranging from the apolitical to the politicized. Many fans were drawn to the dance craze of Rock ' $n$ ' roll, but to the few initiates who maintained channels of communication with developments abroad rock carried strong countercultural undertones related to the American antiwar and civil rights movements. Stelios Elliniadis-a later day music producer and publisher with a pivotal role in Greek musical developments and whose involvement with the student movement followed his initiation into rock-is a case in point:

We got politicized through rock. No doubt about it. . . We watched how the movements evolved, etc.; we knew, we knew what time the Black Panthers would wake up, for instance, we knew everything, we had found the channels of information, which was rare. How could one be up to date? And the magazines, too.... When I discovered [the music journal] Rolling Stone at Syntagma Square, only a couple of kiosks brought foreign press, not all of them. (Elliniadis 2013, interview)

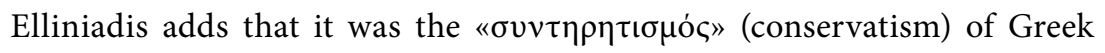
society that was the target of Rock 'n' roll:

There was a conservatism throughout Greek society that would hold you back. We fought, not so much against the junta with rock, but against the conservatism of society, that was the distinctive feature, that was the political component.... Like Turks (today) rebel because kissing in public is forbidden. Ok, it is not only this, but I say that this is what repressed us, that you couldn't grow your hair long, that you would walk in the street and someone from inside a car would shout

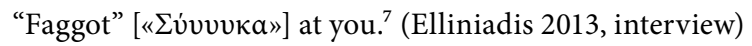

While Elliniadis's account emphasizes social controls on youth appearance and public behavior, to some extent rock music was also associated with freer habits regarding sexuality and everyday conduct. Hippies and people associated with the entire antiwar movement of the late 1960s in the US became frequent habitués of the Greek islands, especially at Matala in Crete at about the same time that the Greek dictatorship reasserted a puritanical way of life (Nikolakakis in this issue). Nudism, sexual promiscuity, and experimentation with drugs were part and parcel of a habitus that shocked locals and fired the 
imagination of young rockers such as Elliniadis-who were, nevertheless, too shy to pursue them openly:

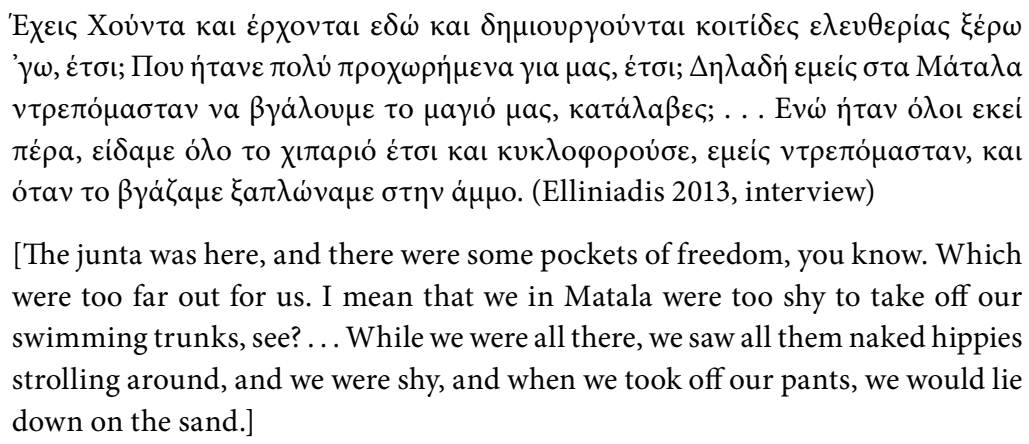

At any rate, hippy-style attires, hairdos, and beards-what Elliniadis calls with

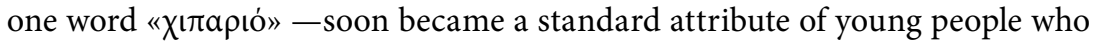
were fascinated with this air of freedom coming from abroad. As historian Nikos Papadogiannis mentions, "dressing normally was portrayed as out of tune with the 'spirit of our times." (Tachydromos 1969; cited in Papadogiannis 2010)

\section{Changing musical topographies in the city of Athens}

It is noteworthy that Athens was segregated along musical but also class and political lines. The regime itself sanctioned a specific form of entertainment, not least through the official institution called the Song Olympiad. According to music expert Anna Papaeti, "organized under the aegis of the Ministry of the Presidency, the International Song Olympiad was the most prestigious and politicized festival in Greece during the dictatorship. It was a popular extravaganza, with a classical title to claim continuity with ancient Greek culture and reap the associated kudos" (Papaeti, forthcoming). Parallel to this, moreover, venues such as dances, parties, and ye-ye-style concerts took place, being tolerated, condoned, or even promoted by the authorities (Papadogiannis 2015, 103). As Dimitris Papanikolaou notes, "the dictators promoted every form of 'low entertainment' as a component of their own nationalistic motto, 'Greece of Orthodox Greeks'” (2007, 94). Urban spaces on the outskirts of the city, especially near the sea, such as Asteras Vouliagmenis, became famous for sponsoring precisely these activities. Moreover, Nikos Mastorakis, the most active music producer of that time, was on very good terms with the regime, had his own television music show, and therefore channeled young people to such venues. 
At the same time, however, the topography of the city included more alternative or progressive music itineraries. Throughout the 1960s, the so-called boites of the Plaka, a traditional neighborhood underneath the Acropolis, had hosted the exponents of Neo Kyma, a musical genre that was based on lyrical ballads of high quality and personal expression and characterized by the young age of its artists, which acted as a counterweight to the previous generation, especially the $\dot{v} v \varepsilon \chi \chi^{\prime}$ (entechno, art song) music of Mikis Theodorakis and Manos Hadjidakis (Kornetis, forthcoming). The habitués of the boites were

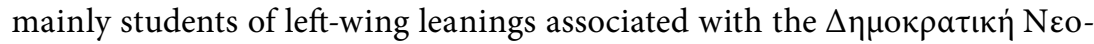

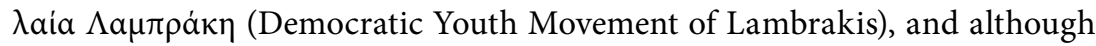
Neo Kyma was not explicitly political, some key exponents wrote songs of political criticism. Savvopoulos was among the most illustrious and political

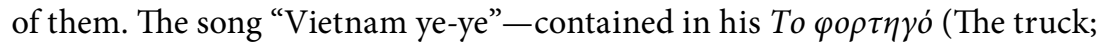
Savvopoulos 1966), an exemplary LP for Neo Kyma in terms of its bare orchestration, Savvopoulos's acoustic guitar, and his singing-is the only song of the period with direct references to the American involvement in the Vietnam War and its devastating consequences (Papanikolaou 2007, 121-122; Kornetis 2013, 19). Savvopoulos, among other artists, most notably left-wing composer Mikis Theodorakis, was targeted by the censors already before the junta and in 1967 was imprisoned for a short period; in fact, he wrote «H $\Delta \eta \mu$ no $\theta \dot{\varepsilon} v o v \varsigma$ $\lambda \dot{\varepsilon} \xi ı$ (Demosthenes' word) while in prison. Theodorakis's music in turn was banned in Greece after the junta came to power, a situation that continued even after the regime lifted censorship of theater and literature. Accordingly, the buying, selling, transmission, reproduction, or lending of Theodorakis's music became a court-martial offense. Soon not only his music but his entire Gestalt turned political, rendering him a powerful icon of resistance, a status reinforced by his legendary escape from arrest for many months after the coup. Many commentators have seen Theodorakis as the embodiment of the spirit of liberty in the 1960s, as well as the engagé artist par excellence (Holst 1979, 132; Papanikolaou 2007, 93; Kornetis 2013, 191).

The seven-year period of the dictatorship saw the demise of Neo Kyma through the imposition of censorship and the gradual closing down of the boites but also the passage of several artists to either a more popular or a more political musical tendency. In 1969, Savvopoulos moved from the Plaka to Rodeo, a basement club that was decorated like a saloon, and subsequently to Kyttaro, both located in a different area of central Athens, on Acharnon Street, close to Victoria Square and the Athens Polytechnic (The National Technical University of Athens). A main reason for his relocation was that he could no longer perform in the Plaka. His relocation signaled and to some extent 
fostered the formation of an alternative countercultural nucleus in central Athens. The new sonic practices that were inscribed in the neighborhood of Rodeo but especially Kyttaro enabled an unusual encounter and synthesis of up until then distinct musical genres and youth groups.

Unlike the tight squeeze of the tiny, smoky boites of the Plaka, Kyttaro (Cell) was a large hall that resembled a small theatre, with a capacity of around 500 people. Its name was apparently chosen by Savvopoulos himself as a reference to the "new cell" in the music scene, ${ }^{8}$ but also as a reference to the psychedelic hippy clubs abroad and their light shows. It had some tables with chairs, as well as a gallery and dressing rooms below. It was located in a middle class neighborhood and therefore had little of the underground character of some of the early boites. The people frequenting the club were a mixed group composed predominantly of teenagers and young adults in their twenties, but also music lovers in their thirties and forties. Also attending, especially Savvopoulos's performance, were literati and artists of progressive circles, such as the troupe of the most avant-garde of all theatre groups of the time, the very political theater collective E $\lambda \varepsilon \dot{v} \theta \varepsilon \rho 0$ $\Theta \dot{\varepsilon} \alpha \tau \rho$ (Free Theater), as indicated by Yorgos Kotanidis, one of its leading actors and a prominent member of the

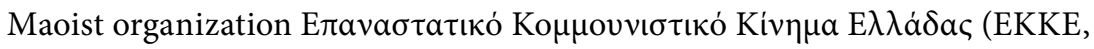
Revolutionary Communist Movement of Greece) (Van Steen 2015, 272-291; see also Kotanidis 2011, 265). Other regular habitués were musician and composer Manos Hadjidakis, poets Nikos Gatsos and Yannis Ritsos, university professors, and other artists and intellectuals. Despite its size, the club was habitually packed with people who came to listen attentively rather than dance-a fact that differentiated it from spaces that were mostly designated for the so-called ye-ye crowd, which the persecuted left of the time considered to be a mostly apolitical subculture that mimicked the youth in France and Great Britain.

The musical events at Kyttaro were an eclectic mix. Dynamic representatives of the emerging rock scenes performed alongside Savvopoulos, whose relocation to Rodeo and Kyttaro occurred at the same time as his purported conversion to rock and his collaboration with rock band Bourboulia-a band with a carnivalesque reference evoking a Bakhtenian subversion of power. Socrates was a hard rock band unique by Greek standards of the time. Apart from original songs, they also covered the songs of Jimi Hendrix, Led Zeppelin, the Rolling Stones, and others, creating a distinctive sound that distinguished them from other Greek rock acts of that period. The songs of rock band Exadaktylos (six-toed) with Dimitris Poulikakos were mainly in Greek and were characterized by an intense surrealism in content and theatricality in performance (Figure 2). Poulikakos, who was also an actor, had been part 


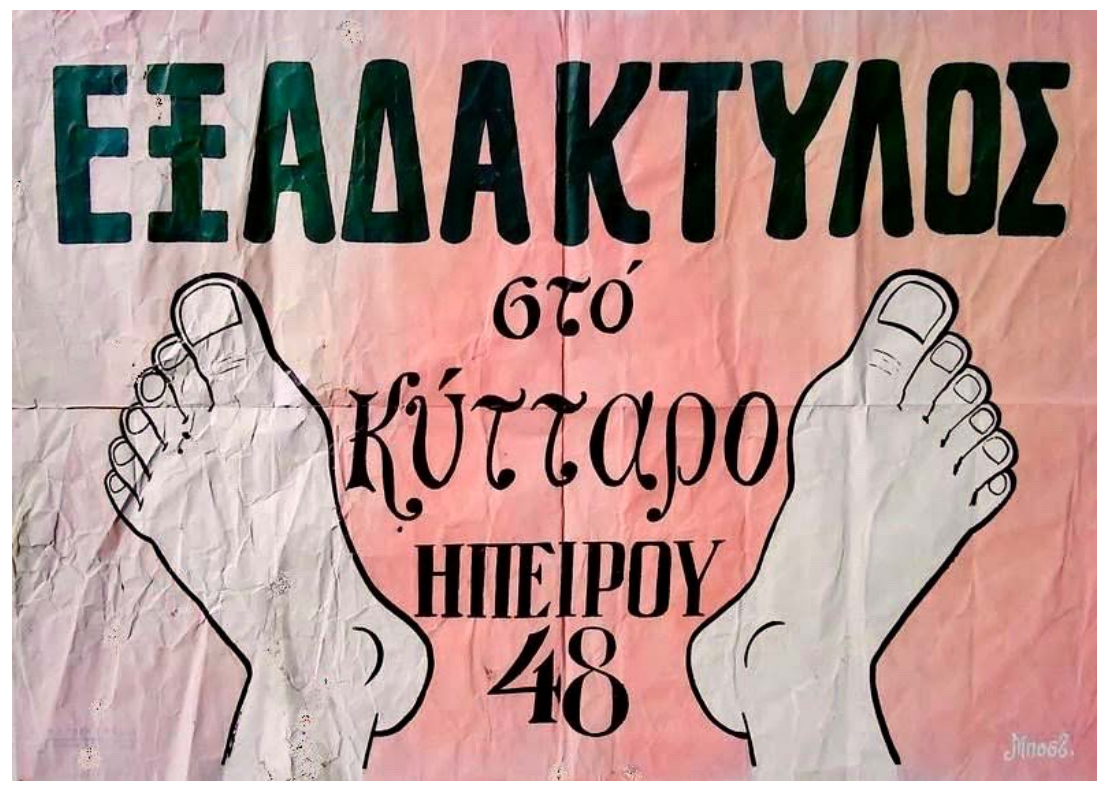

Figure 2 Promotional poster for Exadaktylos in 1972, designed by the well-known left-wing artist Mentis Bostantzoglou (Bost). Source: Courtesy of Kostas Vostantzoglou

of the publishing team of Pali (1963-1967), an avant-garde literary magazine inspired by surrealism and the culture of the beat generation. ${ }^{9}$ The duo Damon and Feidias by Pavlos Sidiropoulos and Pantelis Deligiannidis sang original rock ballads in Greek that contained significant social criticism; its bare orchestration (vocals, acoustic guitar, percussion) was akin to Neo Kyma. Here it has to be noted that most of the above musicians experimented with drugs at the time-an element akin to the international Rock ' $n$ ' roll scene of the time (Papanikolaou 2007, 133; Falireas 2011, 315-320).

\section{Within the affective Cell}

The LP Live at the Kyttaro-Pop music in Athens ([1971] 1996) is a rare example of a live recording at a club in the early 1970s. It features the aforementioned bands and gives a sense of the warmth of the audience reception. The sheer loudness of the electric sound is astounding: all the bands featured (except Damon and Feidias) employ the rock staples of bass, drums, and electric guitars, accompanied in some cases by winds and/or a synthesizer. The live atmosphere is reinforced by the cheers, applause, and whistling of the crowd, which 
are heard not only at the beginning and end but also at key points of each song-after solos, for instance. The live recordings offer just a son ic record of the Kyttaro sessions that fails to render the sensorial experience in all its fullness. Despite this, an overall sense of intimacy is clearly detectable: the crowd responds to the bands' cues, animating them and eliciting an affective performance.

In his analysis of popular formations, Lawrence Grossberg introduces the notion of affect in order to explain why popular culture matters. Affect, according to Grossberg, "defines a structure and economy of belonging" (1992, 84). This description resonates with more recent analyses of popular music and trance that highlight notions of belonging and community building. In his ethnographic study of clubbing, for example, geography researcher Ben Malbon focuses on the clubbing experience as "a form of togetherness in which a central sensation is one of in-betweenness" (1999, 73-74)..$^{10}$ Through movement, physical proximity, and touching, as well as a positive identification with the others and the music, clubbers "can slip between consciousness of self and consciousness of being part of something much larger" (1999, 73-74). In a similar vein, Hesmondhalgh assesses music's ability to enhance feelings of shared experience, attachment, and solidarity in the context of public sociable events $(2014,87)$. The special connection between music bands and their audience at Kyttaro, perceptible in the live album, is further corroborated by a young habitué at Kyttaro. Present-day television producer Tasos Aronitis grew up in the neighborhood of Rodeo and Kyttaro and as a student at the nearby Second Boys High School frequented the club, as well as the matinees that the rock bands of Kyttaro gave in central cinemas for an audience composed predominantly of teenagers. He spoke of the remarkable energy of the audience and likened the auditory experience to a $\pi a v \eta \gamma u ́ p \mathrm{(feast)} \mathrm{(Aronitis} \mathrm{2013,} \mathrm{interview).}$ He also explained that those sounds were fresh and novel, and the only way for young people to listen to them was in live performance. He added:

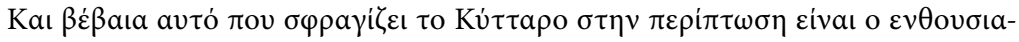

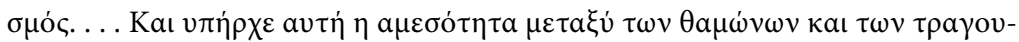

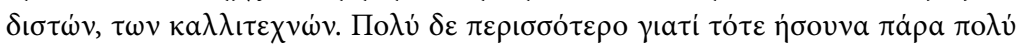

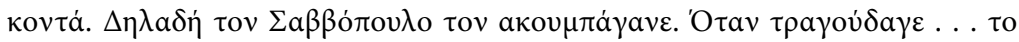

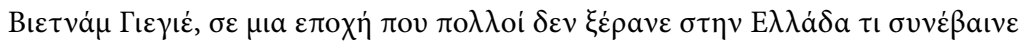

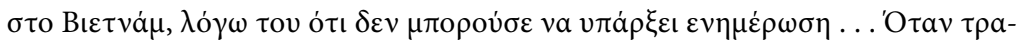

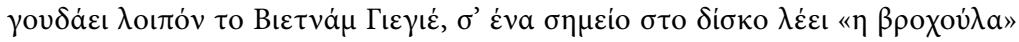

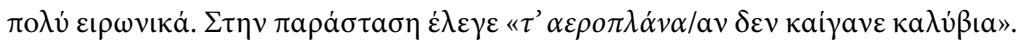

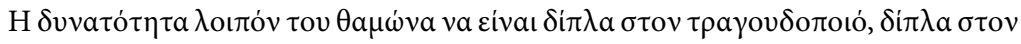

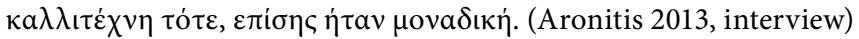


[And, of course, what marks Kyttaro in this case is the enthusiasm. . . There was this immediacy between the habitués and the singers, the artists. . . All the more so because back then you were very close. I mean people could touch Savvopoulos. When he sang ... "Vietnam Ye-ye," at a time when many Greeks didn't know what was going on in Vietnam, because there was no (access to) information ... so when he sings "Vietnam Ye-ye," at one point in the LP he says "a drizzle" very pungently. In the show, he would say "if the airplanes / didn't burn the huts." So the ability of habitués to be next to the troubadour, the artist, back then was also unique.]

The performances at Kyttaro did not engage the senses of hearing and seeing alone or in isolation. They constituted a multisensorial field, which engaged bodies in affective and sensory encounters and merged sound, vision, movement, and touch into a single synaesthetic experience. ${ }^{11}$ Savvopoulos's performance especially was a multimedia show that energized the full sen-

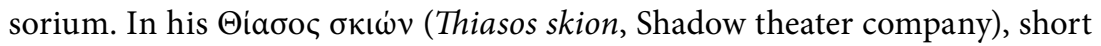
films by auteur Lakis Papastathis and shadow theater by Evgenios Spatharis intertwined with the band's acts. Street fighter Jimmy the Tiger-an almost Fellinian figure culled from La Strada-also took part; when he mounted the stage, people would jeer at him as would happen if the performance was taking place out in the street. At least for some people, his act provoked intense bodily reactions. Stella Gadedi, an avant-garde flautist who played with Savvopoulos

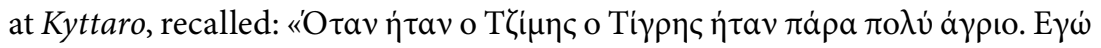

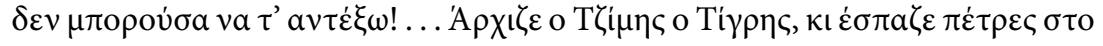

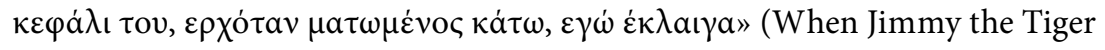
appeared it was extremely wild. I couldn't bear it! . . . Jimmy would start the show, and he would begin to smash stones on his head, and he would exit [the stage] bleeding. I used to cry; Gadedi 2013, interview) (Figure 3).

Both in Aronitis's case above and Gadedi's one here, we notice the importance of multisensoriality in terms of the reception of the show. Aronitis's discourse, on the one hand, focuses on the tactile elements inextricably connected to the experience of listening at the space of the Kyttaro ("you were very close... . People could touch Savvopoulos"), thus indicating a particular kind of connectivity and a powerful intimacy between performers and audience. Gadedi's memory of how the show acted upon her, on the other hand, stresses the visceral attributes that the show produced on her body ("I couldn't bear it. ... I used to cry"). All this resonates well with Grossberg's suggestion that popular culture works "at the intersection of the body and emotions" (1992, 79). Popular culture "inscribes its effects directly upon the body," producing, for instance, tears, laughter, hair tingling, screams, and spine shivering. "These 


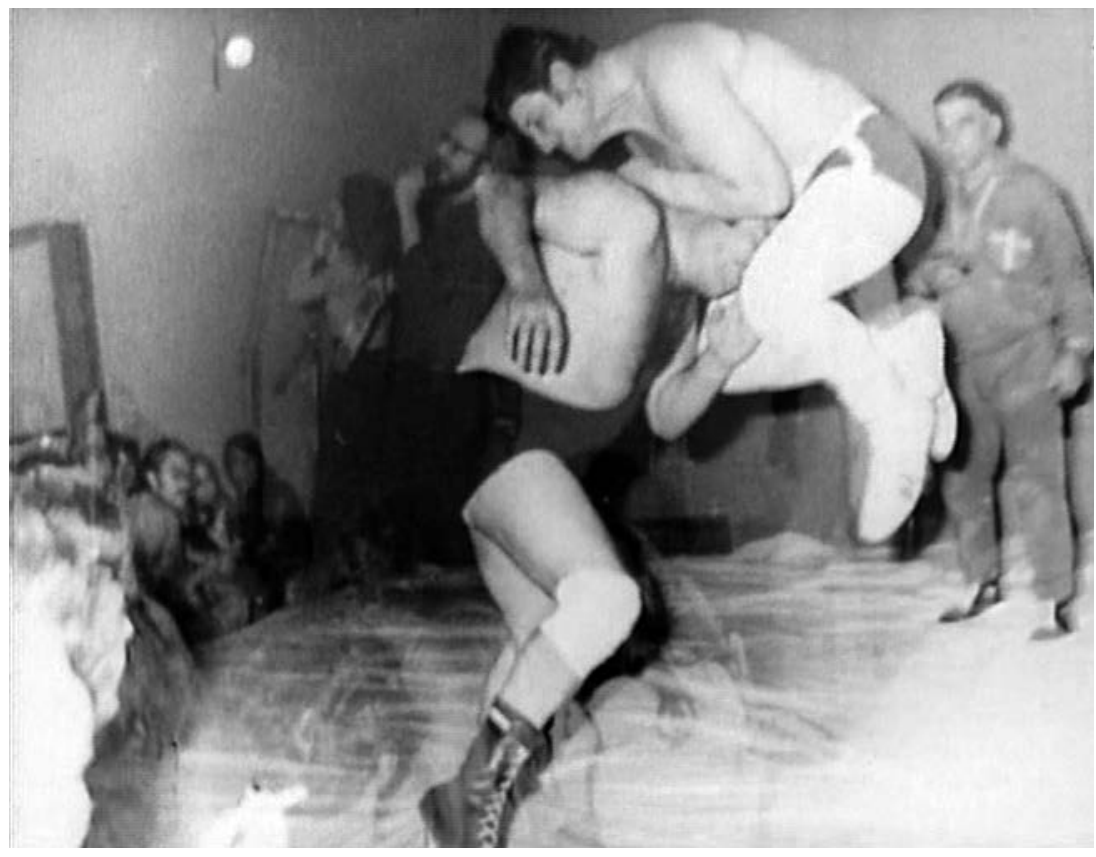

Figure 3 From Lakis Papastathis's tribute to Savvopoulos. One can discern Jimmy the Tiger's wrestling - an almost Fellinian image culled from La Strada - and a superimposed image of Savvopoulos and Gadedi performing right next to him. The images allude to the pastiche created by Savvopoulos's show in the club. Source: Courtesy of Lakis Papastathis.

visceral responses, which often seem beyond our conscious control, are the first mark of the work of popular culture: it is sentimental, emotional, moody, exciting, prurient, carnivalesque, etc." (Grossberg 1992, 79).

Synergies beyond folk, rock and rebetiko

As suggested above, Kyttaro was much more than a rock venue. Between 1970 and 1974, it offered a space of interaction between musical genres and between youth groups whose borders only a few years ago had been clearly demarcated. It is thus the openness to experimentation and new encounters that marked Kyttaro and largely generated its countercultural energy. The resulting fusion of the music idioms of solid rockers with those of Neo Kyma or avant-garde music, or even Greek popular music in the case of Thiasos skion, enriched and infused them with new meaning in the underground context of Kyttaro. ${ }^{12}$ 
Folk music is exemplary in this respect: the authoritarian regime had appropriated it as a national flag and a symbol of the true Greek spirit, accompanying its public announcements and representations with musical idioms of mainland Greece. The eclectic incorporation earlier on of elements of folk music in the work of a few politically engaged entechno composers, most notably Theodorakis and Yannis Markopoulos, helped in shaking off negative associations of folk music with the dictatorial regime and in generating new musical and social contexts for it (Kallimopoulou 2009, 17-23). There was a strong divide between Theodorakis and $\mathrm{S}$ avvopoulos, who r epresented continuity with the avant-garde New Wave of the Greek song of the early 1960s but also a break with it, in a Bob Dylan-esque way. Apart from Dylan, Savvopoulos's raw model was Georges Brassens, the French anarchical "singing poet" who fused folk song elements canonized as "oral poetry" with identifiable popular song (Papanikolaou 2007, 24).

At Kyttaro, folk music was reworked into experimental, electric, and rock idioms, thus reinforcing the work of Theodorakis and Markopoulos and expanding folk music's counter hegemonic associations to the young generation. Savvopoulos's songs expressed the fragmentary, solitary experience of contemporary Greeks using a musical language that merged elements from a variety of Greek urban and folk traditions. His purported conversion from Neo Kyma to rock in the late 1960s, when he went electric (not unlike Bob Dylan a few years earlier), established him as an iconic figure of "Greek rock" or "Balkan rock," who achieved a genuine synthesis of rock with Greek popular music. The vocal trio Anakara sang traditional songs of Veroia, their hometown in Northern Greece. Arranged for three voices, two acoustic guitars, the flute, and the frame drum ( $v \tau \dot{\varepsilon} \varphi \mathrm{\iota}$, defi), "not in the traditional way of folk songs but with an innovative spirit influenced by the rock sounds of that time" (in the words of Anakara member Kostas Georgiou [Rockap.gr 2010]), the songs sounded more aesthetically pleasing and "digestible" to urban youth.

All these experimentations with folk music challenged the authoritarian regime's monopoly over the definition of the meanings of tradition and folk song (Kallimopoulou 2009, 20-23). Mariza Koch, a singer and songwriter whose voice and singing style had been likened to that of Janis Joplin, explains this process as follows:

The people who came to that sort of thing were politicized.... They wanted to say, "I'd like to hear folk songs but without a state official announcement following." Do you get it? It was as if they took away from the junta establishment, as if they took away the very power of the song, so that [the junta establishment] wouldn't use it. (Koch 2013, interview) 


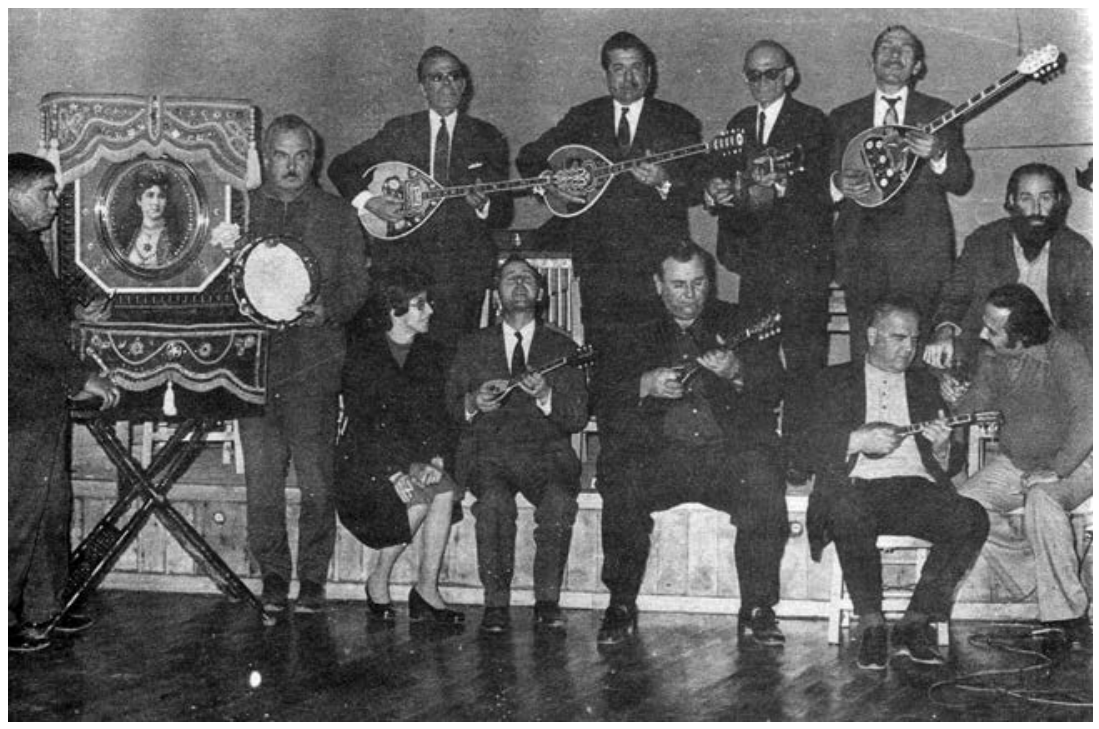

Figure 4 Old rebetes performing at Kyttaro in 1972, next to urban folklorist Elias Petropoulos (far right, with the beard). Notice the presence of the laterna on the far left, heralding the growing interest in popular culture among the progressive urban youth in the 1970s. Source: The photo published in Tomes (69, February 1981), a monthly journal on the arts, directed by poet Dimitris Doukaris. (We are grateful to Fontas Trousas for this information.)

Koch herself moved during the junta from the boites of the Plaka to Rodeo and Kyttaro, where she performed folk songs from Asia Minor and the Aegean islands adapted for an electric band, blending folk with electric as precisely a means of "taking away the very power of the songs" from the junta and rendering it to a progressive audience that was starved for different stimuli.

Apart from forging antiregime associations with folk music, the Kyttaro nights were also key in introducing the rebetiko genre in the form of tribute nights, further augmenting the political energy of the club. These were coorganized by Savvopoulos together with rebetiko aficionado and urban folklorist Elias Petropoulos. In the context of these tributes, the exponents of the old generation of rebetes, such as Michalis Genitsaris, Giorgos Mouflouzelis, Stelios Keromytis, Takis Binis, would all perform together (Savvopoulos 2004b, interview) (Figure 4).

In fact, Savvopoulos himself collaborated with emblematic rebetiko

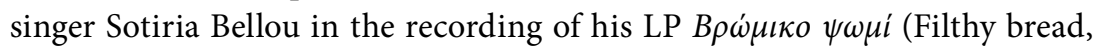
1972). Thinking back to these performances at Kyttaro, Savvopoulos is keen to differentiate between earlier reappropriations and the resurgence of interest in 
rebetiko in the 1970s, stressing that the latter was strongly associated with leftwing students reacting against the regime. In his words, young people would specifically ask for songs with an explicit content that referred to the 1940s resistance against the Axis Occupation, inevitably forging associations with the repression of the junta years:

The revival of rebetiko song in the 1970s had clearly a content of resistance ... Songs that were in high demand were, for instance, "I'll jump, I'll jump, and I'll swipe their cans off their trucks." This resurfaces in the 1970s with a different meaning altogether, as it contains a reference against the Germans. ${ }^{13}$ (Savvopoulos 2004b, interview)

According to Savvopoulos, the rebetiko songs that were especially popular in the 1970s revival would often carry political connotations, such as the abovementioned $\sigma \alpha \lambda \tau \alpha \delta$ ó $\rho \circ$ (saltadoros) song, or focus on drugs, the so-called $\chi \alpha \sigma ı \lambda i_{i} \delta \kappa^{\alpha} \alpha$ (songs about hash). ${ }^{14}$

As for the composition of the audience, the sessions at Kyttaro offered in reality a rare space of coexistence and interaction between two spatially and semantically separate subcultures until that point: on the one hand, the ye-yes, who listened mainly to rock'n'roll, and, on the other hand, the left youth, who were involved in the student movement and listened to political songs (Kallivretakis 1994; Bozinis 2007; Katsapis 2011). Artists such as Savvopoulos, Mariza Koch, or singer/songwriter Thanasis Gaifyllias bridged the worlds of rock and political song and rendered themselves relevant to both audiences. As Nikos Tsioulakis, drummer for Thanasis Gaifyllias in the early 1970s, pointed out, "Gaifyllias, in particular, had it both ways. While his music was rock, his lyrics were politicized." In fact, several Gaifyllias's songs had anti-junta references and attracted a politicized audience at Rodeo and Kyttaro (Tsioulakis 2013, interview).

Kyttaro became thus a meeting place and a melting pot for both the hitherto apolitical youth, meaning the former ye-yes, who were typically more interested in lifestyle than politics, and directly politicized students. Music played a key role in transforming Kyttaro into a space that permitted the imagining, and even the fashioning, of new collectivities in an embodied and affective manner. At this particular historical juncture, the performance events at Kyttaro produced an "affective empowerment" that involved "the generation of passion [and] the construction of possibility" (Grossberg 1992,

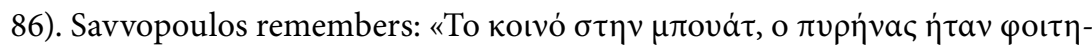

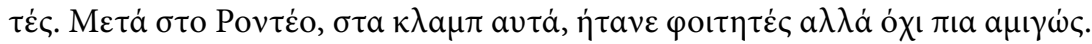

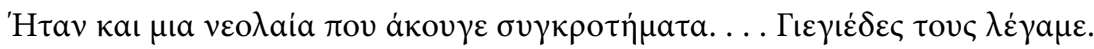




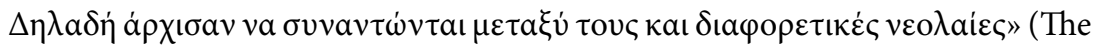
main audience at the boites were students. At Rodeo, in those clubs, there were students but not [an] unmixed [group] anymore. Youth were coming, as well, who liked to listen to rock groups.... We called them ye-yes. Different kinds of youth started meeting each other; Savvopoulos 2004a, interview, quoted in Kornetis 2013, 196). This mixture, which led to the creation of a new youth culture combining political with countercultural features, ${ }^{15}$ was also visible in the appearance of the youth. The militants started adopting the ye-ye look, wearing long hair and beards-in a meaningful change of style that brings to mind the seminal work by Dick Hebdidge on shifting subcultural codes $(1979,46-54)$. The opposite was also true, as Panos Theodoridis, a student who

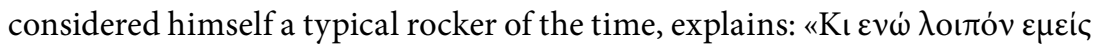

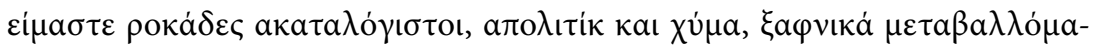

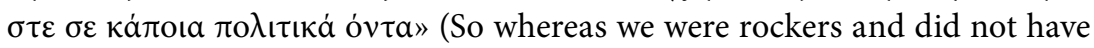
responsibilities, being apolitical and cool, all of a sudden we got transformed into political creatures; Theodoridis 1998, 322). While historian and student activist at the time Leonidas Kallivretakis asserts that students left rock culture behind when they were organized into antiregime political groupings (1994, 172), in reality rock and politics coexisted.

There $\mathrm{w}$ as a lso $\mathrm{t}$ ension, h owever, s temming f rom c ertain a udiences' expectations, in cases in which the latter did not necessarily appreciate Kyttaro's hybrid style. Savvopoulos describes thus the reception and composition of his own audience following his relocation from the Plaka to Rodeo (and then Kyttaro):

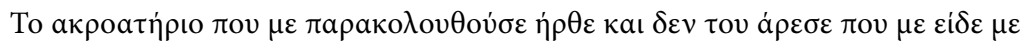

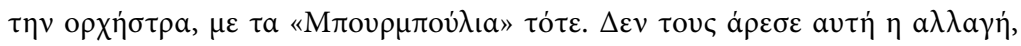

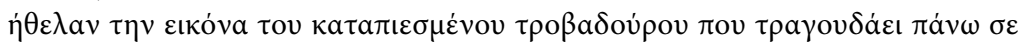

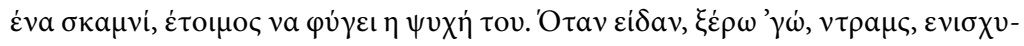

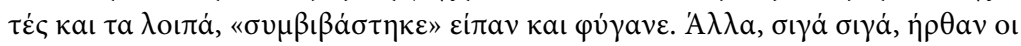

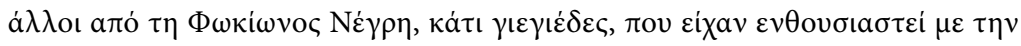

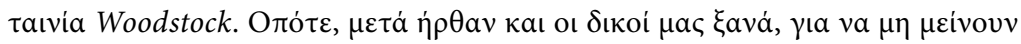

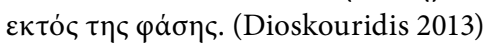

[The audience that usually attended my performances came and resented seeing me with Bourboulia, my band at the time. They didn't like this change, they clung to the image of the oppressed troubadour singing seated on a stool, longing to bare his soul. As soon as they saw the drums, the amplifiers and the like, they said "he has sold out" and left. But gradually the other folk from Fokionos Negri came, ye-yes, that's who they were, who were thrilled with the film Woodstock. So then our folk returned, not to miss out on things.] 
As Savvopoulos very consciously mimicked Bob Dylan, not only in terms of music but also his persona and provocations, one cannot but note here the similarity between this and Dylan's rejection by his audiences ever since he "went electric" at Newport Folk Festival in 1965 (Théberge 2001, 13). The va rious transformations of Savvopoulos equally earned him fanatical supporters but also enemies. In contrast to Mikis Theodorakis, who remained faithful to the epic-heroic genre, encapsulating the communist spirit of the time in terms of resistance and marking continuity with the past, Savvopoulos liked ruptures, and Kyttaro offered him the ideal terrain to bring them about.

\section{"I wanted the sound to hit me right here!": Asserting the political via the senses}

The m usical c rossover of the Kyttaro s essions b rought a nd linked together unlikely groups. The affective nature of the experience-shaped by bodies in close proximity and the electric sound and high volumes which hit body and senses $^{16}$ - and the countercultural element were important factors in rendering the experience powerful and meaningful to the young people who attended them. The fact that in the early 1970s, when the antidictatorship student movement was still low-key, major events of such transgressive intensity took place in Kyttaro, in which avant-garde musicians were jamming together with the underground rock scene of Athens, indicates the explosivity of Greek counterculture and the central role of this venue in the formation of an oppositional space.

The potential subversiveness of performances at Kyttaro is demonstrated also by the fact that the sessions were reportedly attended regularly by the regime's men (Papastathis 2013, interview). Director Lakis Papastathis recalls himself and Savvopoulos being summoned to the censorship bureau and questioned about the lyrics of one of his songs, «To $\mu \omega \rho$ o'» (The baby, included in

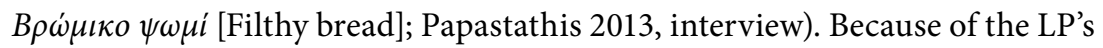
title and subject matter, Savvopoulos was reprimanded for insulting the Greek bakers - a fact that also indicates the low standards of Greek censors at the time and their basic inability to grasp allusions, a fact that rendered the latter the major tool of alternative Greek artists, mostly musicians and film directors: ${ }^{17}$

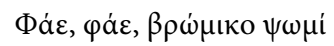

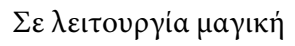

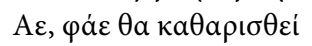

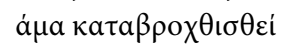

[Eat, eat, filthy bread

In a magical liturgy 
Eat, it will be purified

Once devoured]

Savvopoulos communicated through this song one of his major ideas at the time: that tradition, a typical tool of the Colonels' propaganda mechanism, as mentioned before, and hence traditional songs could be inverted and subverted, thereby being used against the regime's own hypocritical use of it. In Karen Van Dyck's conclusion, the seemingly paradoxical embrace of folk culture by this alternative sphere, represented by Savvopoulos, was the equivalent of the physician's homeopathic cure, whereby "that which is threatening can be used to strengthen the immune system" $(1998,51)$. The clearest indication of this method was offered not only by Savvopoulos and Mariza Koch's reworkings and new renderings of traditional songs but also by the abovementioned song, which focuses on the sensory feel of homeopathy-a liturgical, purifying, but also deeply physical practice. Savvopoulos in an interview in 1972 gave very clear insights into this methodology-referring directly to "filthy

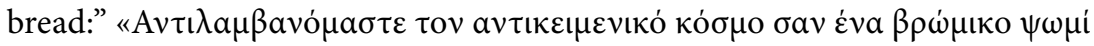

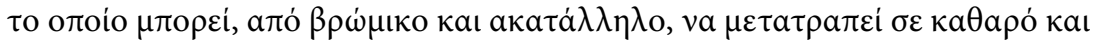

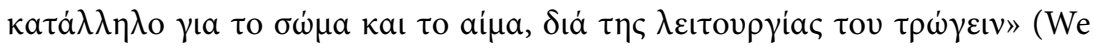
conceptualize the material world as a piece of filthy bread which could, from filthy and unhealthy, be transformed into clean and healthy for the body and the blood, via the process of eating it; Mitras 1972, 215).

Director Lakis Papastathis offers his view on the overwhelming experience of listening to that song live:

Just imagine-you who are kids compared to me-being at the Museum and turning onto Epeirou street to go to Epeirou and Acharnon and going inside and hearing, "Eat, eat the filthy bread / In a magical liturgy / Eat, it will be purified / Once devoured." Where else would you hear such things? (Papastathis 2013, interview)

Papastathis's view helps us conceptualize the audience at Kyttaro as a mystical community of initiated spectators that metabolized the "filthy bread" of tradition, rock, and alternative counterculture through the practice of consuming it in everyday doses. This transformative process could also be likened to an experience of healing comparable to shamanic, ecstatic healing (Hutson 2000).

Moreover, and in sensory terms, the loud electric sound, which at the time was identified especially with Rock ' $n$ ' roll, seems to have offered to the youth an unprecedented vehicle for empowerment. This experience was physical and overwhelming. It hit the body and touched the senses, and it remained a vivid memory decades later. Giorgos Gavalas played bass for Savvopoulos at Kyttaro. 


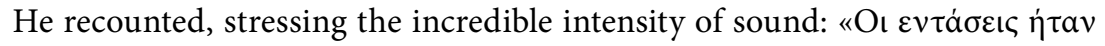

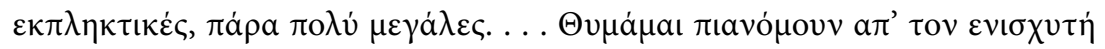

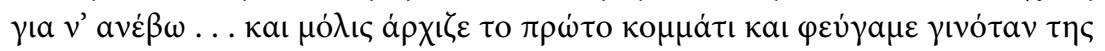

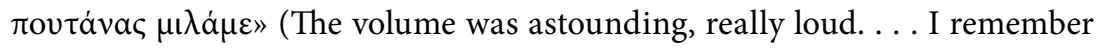
that I used to grab the amplifier in order to go up on stage ... and when the first piece started and we got going, it was wild, man; Boskoitis 2005, 21:43]. Stella Gadedi, who was 18 years old when she joined Savvopoulos and Bourboulia at

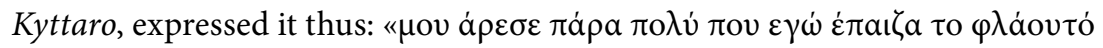

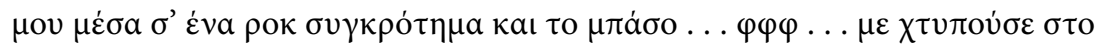

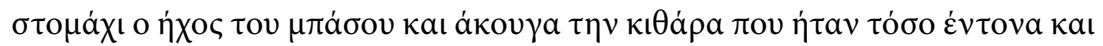

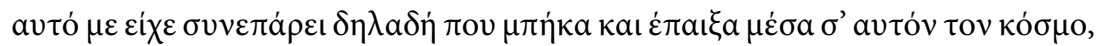

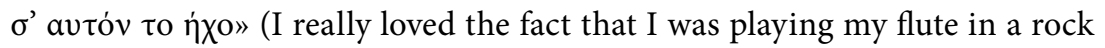
band and the bass ...fff ... the sound of the bass pounded in my stomach, and I heard the guitar which was so intense, and I was enthralled by this, I mean, participating in this and performing for this kind of crowd, this sound; Boskoitis 2005, 20:46). Gadedi's description underlines the intense physicality of the

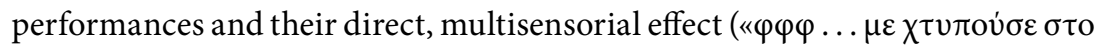

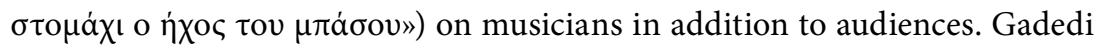

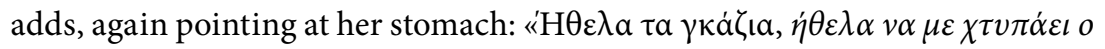

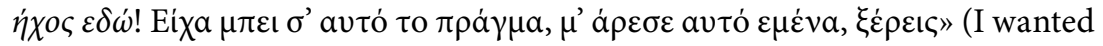
the rush. I wanted the sound to hit me right here! I was inside that thing, I dug that, you know; Gadedi 2013, interview, our emphasis). The synaesthetic expe-

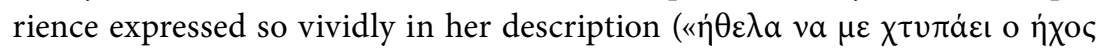
$\varepsilon \delta \omega \dot{t} !)$ was produced by a discrete "sensorial assemblage" (Hamilakis 2013, 126-128). The distinctive Kyttaro soundscape (music and lyrics), the circulation of alcohol and drugs, intense tobacco odor, late hours, dim lighting, and pounding rhythms, as well as the affective interaction between performers on stage and audience below-all these combined to engage the senses (Figure 5).

The high degree of informal audience participation, from raucous clapping to communal singing, eliminated the distance between auditors and performers and reinforced the sensorial and corporeal flows through shared feelings of group identity and a propensity towards political defiance. This sensorial regime was manifestly at odds with the "established sensorial order" that Hamilakis describes (after Jacques Rancière) $(2013,70)$. Furthermore, it directly undermined the public events sanctioned by the regime (for example, the Song Olympiad or the ye-ye style concerts mentioned above), whereby bodily movement and sensory interaction were regulated, and to an extent disciplined, through clearly delineated rules of conduct. ${ }^{18}$ Song Olympiads that tried to promote the image of a (pop) culture-loving Greece were characterized 


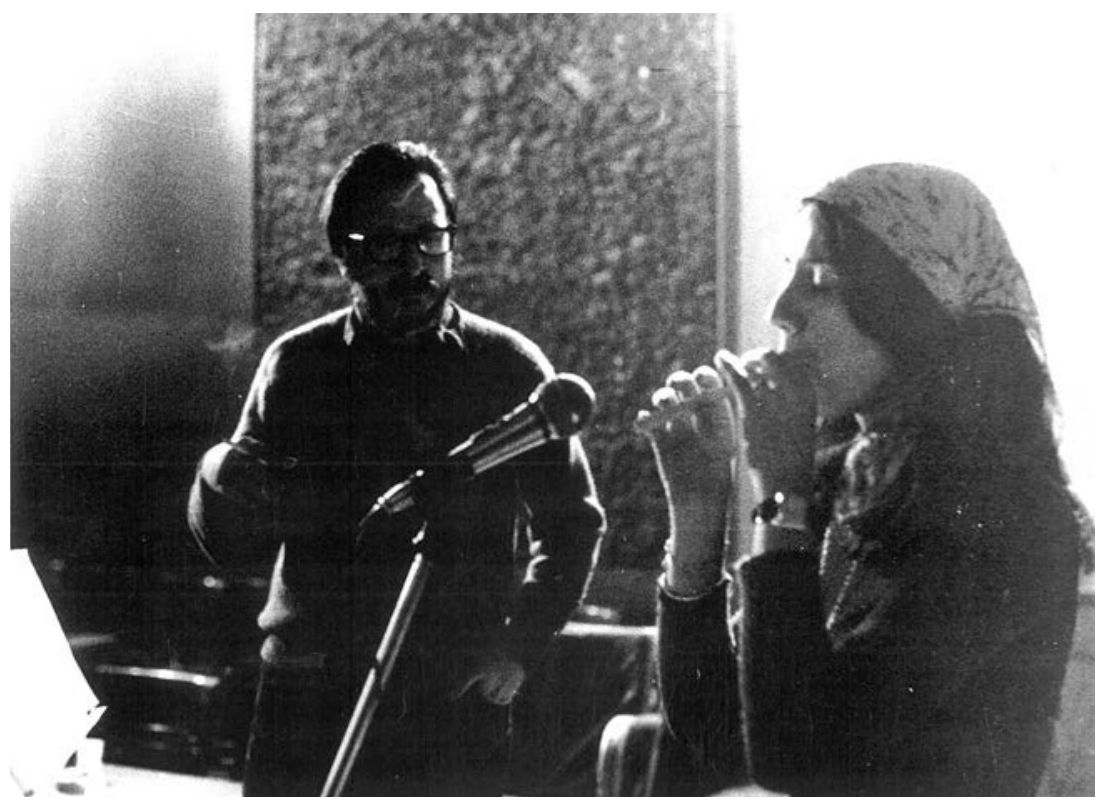

Figure 5 Still image of Stella Gadedi performing next to Savvopoulos. Gadedi, an accomplished flautist, recalls the intense physicality and multisensorial power of the performances. Source: Courtesy of Stella Gadedi.

by a disciplined and regulated structure of the image-with the artists on an enormous pedestal and an entire orchestra performing below. These indicated a huge contrast with the sensorial disorder of the Kyttaro sessions.

All this in an intense, but magical way-to quote the words of the aforementioned song once more-transcended the space of Kyttaro, rendering it a central space of antiregime activity and youth politicization. Papastathis stresses this fact, singing along to a snippet from Savvopoulos's song, imitating his voice (Figure 6):

When Savvopoulos sang "oh, I jump, I bunny-hop"-one of the greatest things

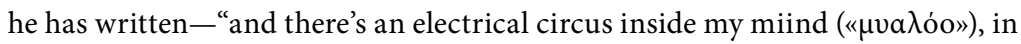
my mind that has limits ("ópı "freedom," led to an antijunta delirium! (laughter) (Papastathis 2013, interview)

Koch explains it in her own words, which, like Papastathis's comment, empha-

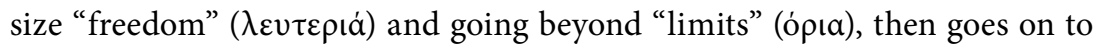
describe the underground circulation of = music with political messages, and even suggest a ritual healing: 


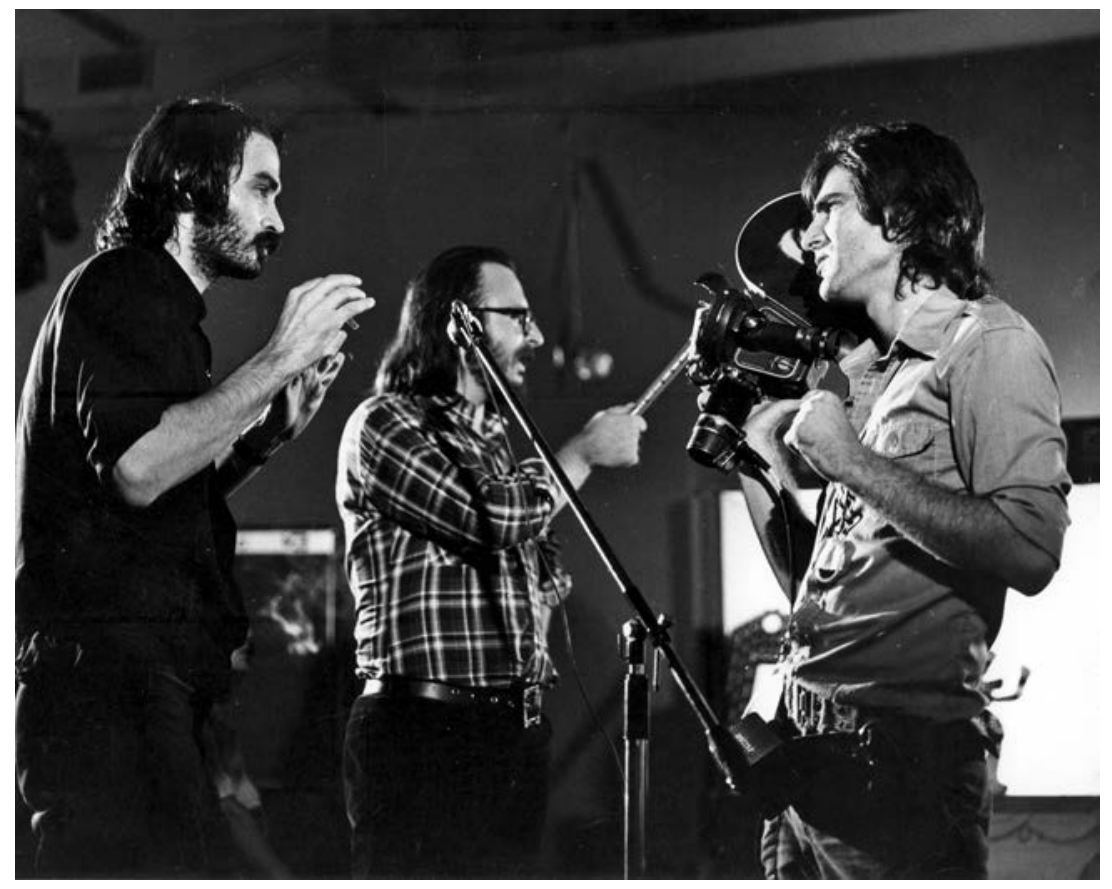

Figure 6 Still image of director Lakis Papastathis giving directions to his cameraman, who is filming the Kyttaro sessions, next to Savvopoulos in the background. Source: Courtesy of Lakis Papastathis.

In reality, I would say that this was for young people a window to freedom

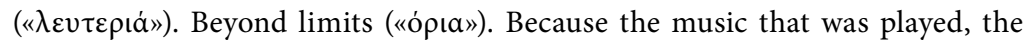
sounds, the final sonic result was entirely rock. And, of course, there was no discography that would arrive easily in Greece, but as we were music hounds, we found ways to find out about what was going on in the world. And to be influenced by it. ... And with the absence of political song, which circulated only in a subterranean way-it was only whatever arrived from Mikis from abroad-the

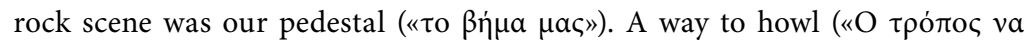
oup $\lambda ı a ́ \xi \varepsilon ı \varsigma »)$. Justifiably. (Koch 2013, interview)

The phrases "pedestal” ( $\xi_{\varepsilon เ \varsigma)}$ are key to understanding the bridge from music to politics. Young people sought out music to express their pent up feelings. The musicians worked hard

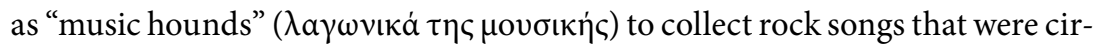
culating abroad, a substitute for political songs that could not be found except underground. Rock thus reached audiences from a high point, a "pedestal," 
or even "altar," and encouraged the audience to express their justifiable pain. Thus the Kyttaro sessions were formed by a powerful community of alternative artists and audiences with a direct political effect. This political effect passed in a ritualistic way through the body and the senses. Despoina Glezou similarly recounts in the promotional spot of Boskoitis's aforementioned documentary that even international artists-such as Michael Wadleigh, the director of Woodstock-were touched by the atmosphere and the combative ambience of the space and its habitués:

Some amazing nights at the Kyttaro were a total confirmation of the beauty that emerged from inside this place. Mike Wadleigh, who directed the film Woodstock came, Cat Stevens came, Richie Havens, the black performer who sang "Freedom" at Woodstock, came, and they all left completely enchanted. I mean the nights were so powerful that these people with all their experience, who had experienced thousands of people when they performed at Woodstock and who made Woodstock, were enchanted by us! (Boskoitis 2005b, 2:11)

The chronotopical connection between Woodstock and Athens, which Glezou stresses was in fact intensified when in December 1970 the police violently interrupted the screening of Wadleigh's eponymous film, leading to the first spontaneous mass youth protest in the junta years (Papanikolaou 2007, 106; Katsapis 2013, 393-396; Kornetis 2013, 175). Kyttaro had become a site for experimentation and resistance, breeding a nascent political culture that would eventually contribute to the struggle for the overthrow of the junta.

\section{Epilogue}

It was precisely the sensuous and affective nature of the Kyttaro experience that rendered it so potent. It proved to be a meeting point between ye-ye style, rock music, and folk revivals within an overtly politicized context. Things were bound to change, however. After a certain point, the hybrid, allegorical nature of the Kyttaro sessions proved to be too cryptic for the hyper-revolutionary spirit of the time. The student movement that was emerging with the Law School occupations of February and March 1973 and above all the Polytechnic uprising of November 1973, which is the apogee of youth radicalism, needed different idols and showed a strong preference for direct, raw, combative political songs. Theodorakis was setting the tone-a fact that is not only substantiated by testimonies regarding the heroic singings of his songs that were chanted by groups of students defiantly in the tavernas but is further justified by the choice of songs that were played by the pirate radio station that was established 
within the Polytechnic. Savvopoulos expressed his bitterness about this fact in a statement that indicates also the renewed prominence of the neighborhood of the Plaka in the youth geographies of musical resistance:

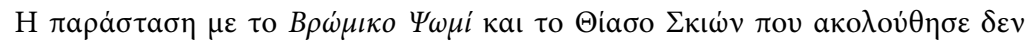

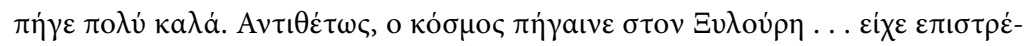

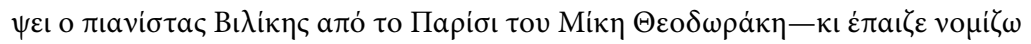

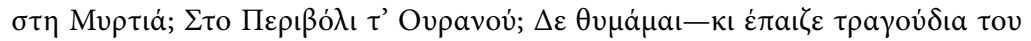

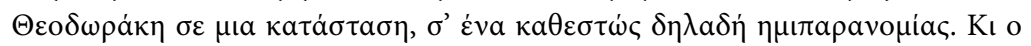

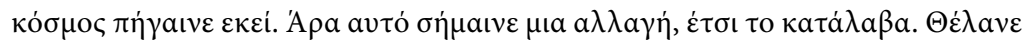

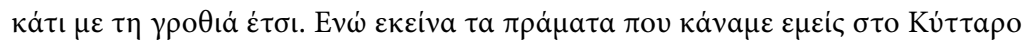

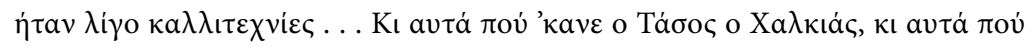

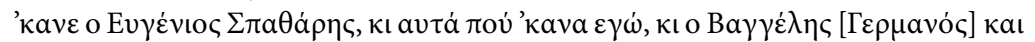

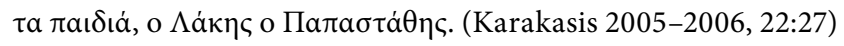

[The Filthy Bread sessions and the Shadow Theatre that followed did not go very well. On the contrary, people would go to Xylouris. Theodorakis's pianist, Vilikis, had come back from Paris-and he performed I think at Myrtia, or at Perivoli t' Ouranou, I can't remember-and he played songs by Theodorakis semi-legally. And people would flock there. So, this signaled a change, this is how I interpreted it. They wanted something with the fist up. While the stuff that we were doing at Kyttaro was a bit artsy... and what Tasos Chalkias did, and Evgenios Spatharis, and what I was doing, and Vangelis (Germanos) with the other folks, and Lakis Papastathis].

However, it is telling that when Theodorakis himself came back from Paris after the fall of the junta, he expressed his astonishment at the popularity of Savvopoulos and the Kyttaro during the junta years. In Theodorakis's mind, there was something dark and nihilist in essence going on in these music sessions that he could not grasp but that he respected, as it apparently struck a chord with the audiences (Theodorakis 2003, 139). ${ }^{19}$ By the summer of 1974, though, the absolute winners in terms of audiences were Theodorakis, Markopoulos, and the other more directly political composers, a fact that was expressed through the great concerts in the stadiums that marked the passage to democracy.

Following the fall of the junta, music retained a central role in articulating the political and social aspirations of Greek youth. It provided a vehicle for voicing in a sensuous and highly emotional way the newly attained sense of freedom and emancipation. As the musical itineraries of political expression changed once again, spreading out and going public, it was the concerts in big stadiums that came to generate the public soundscape of freedom, bringing young and older people into a community that momentarily, perhaps, appeared 
to dissolve generational-and social-differences. A different sort of multisensorial modality was created, in some ways connected to the sensorial and corporeal flows of the Kyttaro world during the junta years, but at the same time also quite different due to the different historical context and the distinct space.

In Andreas Thomopoulos's Aldevaran, a signature film of 1975, we see Poulikakos with Exadaktylos with the help of a bearded brass band performing

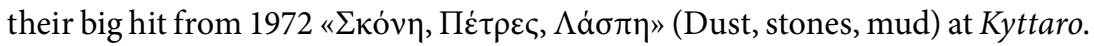
The space had kept some of its energy, and the fiery performances of the band communicate that sensorial experience to even a modern-day spectatorship. The junta had already collapsed, but Kyttaro was retaining its legendary status in these first Metapolitefsi years, in which the dominance of rebetiko and antartika was absolute, thus rendering Greek rock rather marginalized. ${ }^{20}$ Even so, the "rush" ( $\gamma \kappa \alpha \dot{\zeta} / \alpha)$ that Gadedi referred to and the mystical experience of the initiated is still discernible in that 1975 film, albeit without Savvopoulos's presence.

Kyttaro would preserve something of its affective and synesthetic aura for some time, representing an emblematic space in which popular culture and resistance became interrelated and mutually reinforcing, though without a political role to play any longer in terms of shaping young people's consciousness.

UNIVERSITY OF MACEDONIA, THESSALONIKI

CARLOS III UNIVERSITY, MADRID

NOTES

Acknowledgments. We would like to thank Tasos Aronitis, Stelios Elliniadis, Stella Gadedi, Mariza Koch, Lakis Papastathis, Nikos and Liana Tsioulakis, Dimitris and Olga Kourantis, and Nikos Kavoukidis for sharing their time and recollections with us; Andreas Siadimas, Antonis Boskoitis, Yannis Tsioulakis, and Dimitris Varelopoulos for their valuable assistance; and Panagiotis Poulos and Dafni Tragaki as well as Artemis Leontis and the journal's two anonymous reviewers for their critical comments to earlier drafts of this article.

${ }^{1}$ By countercultural, we mean the culture and lifestyle of young people who rejected the dominant social behavior. For a classic definition of counterculture, see Roszak (1969) 1995.

${ }^{2}$ We thank Panayotis Panopoulos for drawing our attention to Friedner and Helmrich's study.

${ }^{3}$ Pioneer social historians E.P. Thompson (1966) and Howard Zinn (1980), among others, originally used the term "from below" in an attempt to historicize the everyday life experience of the lower classes and the labor movement. The term eventually came to denote a way of doing 
history that focuses on ordinary people instead of the elites, and this is how we use it here. Also see in this respect Cerutti 2015.

${ }^{4}$ Sheila Whiteley points up the nonspecificity of counterculture, which had a "significant degree of fluidity such that it could incorporate diverse groupings and, thus, manifest itself differently at specific times and within specific places depending on local socio-economic, cultural and demographic circumstances" $(2012,2)$. On youth culture and cultural politics in Greece before and during the junta, see Kornetis 2013; Katsapis 2013; on the reception and indigenization of rock in Greece, see Bozinis 2007; Katsapis 2007, 2013, 344-400.

${ }^{5}$ At a certain point in Boskoitis's documentary (2015a), one of his testimonies refers to his pop band's tour around the rural areas and the way in which the baffled locals greeted the longhaired and casually dressed musicians.

${ }^{6}$ On the Otherness of these rockers, see also Katsapis 2013, 386-387; Papadogiannis $2015,47$.

${ }^{7}$ Elliniadis recalls being both applauded but also booed when he entered Law School as a freshman in 1968 by his fellow-students because of his long hair (see also Bozinis 2007, 343-344). On the social controversy over the "phenomenon" of long hair among the young, see Katsapis 2013, 410-417.

${ }^{8}$ We owe this information to director Antonis Boskoitis.

${ }^{9}$ On Pali, see Hamalidi, Nikolopoulou, and Wallden 2012, 10. On Exadaktylos and its lyrics and on Poulikakos in particular, see Katsapis 2013, 383-390.

${ }^{10}$ Many studies of popular music and especially trance emphasize the sense of togetherness and community building (indicatively, Hutson 2000; Rill 2006; St. John 2008).

${ }^{11}$ See also Hamilakis 2013, 61-65. Landsberg 2010 notes the special connection between sound and body, which he terms the "aural visceral."

${ }^{12}$ For an elaboration on the notion of the "underground," see Hamalidi, Nikolopoulou, and Wallden 2012.

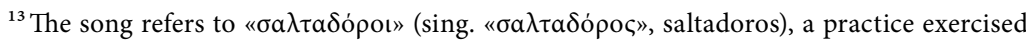
by young saboteurs during the German Occupation, who would habitually jump on German trucks to steal food supplies.

${ }^{14}$ On a general assessment of the 1970s rebetiko revival and the renewal of interest in Greek popular culture and its exponents among the urban youth, see Kallimopoulou 2009, 23-33.

${ }^{15}$ Whiteley observes that despite their underlying tension, politically active students of the New Left and bohemian hippies and yippies (who maintained strong links with rock culture) were "united in their attack on the traditional institutions that reproduce dominant cultural-ideological relations-the family, education, media, marriage and the sexual division of labour. There was a shared emphasis on the freedom to question and experiment, a commitment to personal action, and an intensive examination of the self" (Whiteley 1992, 83).

${ }^{16}$ Malbon 1999 and Jackson 2004 analyze clubbing as an intensely sensory experience.

${ }^{17}$ Papastathis offers a detailed description of this (to some extent hilarious) exchange between the artist and the censors in his book (2011, 85-88).

${ }^{18}$ It is telling that even at the aforementioned concert of the Rolling Stones in 1967, just a few days before the coup, the police prohibited youngsters from dancing: according to one of the organizers, music producer Nikos Mastorakis, the police beat black and blue whoever stood up to dance (Trousas 1996, 34).

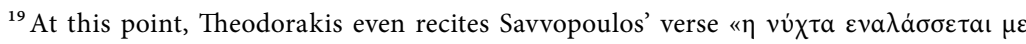
vúxนa» $(2003,139)$. 
${ }^{20}$ As Falireas concluded with bitterness, the "Plaka ended up being the hotbed of the antartiko song, the rebetiko song-the kitschiest things you can imagine" $(2011,239)$.

\section{REFERENCES CITED}

Asimakoulas, Dimitris. 2009. “Translating 'Self' and 'Others': Waves of Protest under the Greek Junta." The Sixties 2 (1): 25-47.

Benjamin, Walter. 1969. "Paris: Capital of the Nineteenth Century." Perspecta 12: 163-172.

Bennett, Andy. 2005. Culture and Everyday Life. London: Sage.

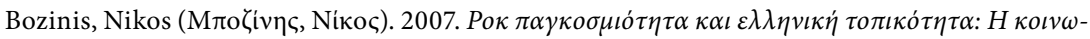

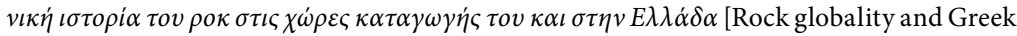
locality: The social history of rock in its countries of origin and in Greece]. Athens: Nefeli.

Cerutti, Simona. 2015. "Who is below? E. P. Thompson, historien de sociétés modernes: Une relecture.” Annales: Histoire, sciences sociales 4: 931-956.

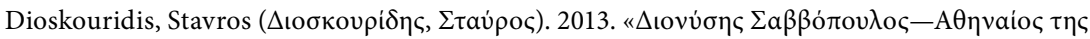
$\varepsilon \beta \delta$ o $\mu \alpha \dot{\delta} \alpha \varsigma_{\text {.» }}$ [Dionysis Savvopoulos-Athenian of the week]. Lifo, 27 February. Accessed 27 October 2017. http://www.lifo.gr/mag/features/3665.

Doukaris, Dimitris. Tomes. 1981. 69.

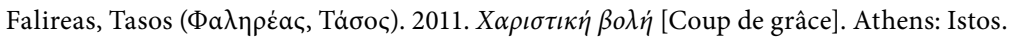

Friedner, Michele, and Stefan Helmreich. 2012. "Sound Studies Meets Deaf Studies." Senses and Society 7 (1): 72-86.

Grossberg, Lawrence. 1992. We Gotta Get Out of this Place. New York: Routledge.

Hamalidi, Elena, Maria Nikolopoulou, and Rea Wallden. 2012. "A Second Avant-Garde Without a First: Greek Avant-Garde Artists in the 1960s and 1970s." In Regarding the Popular: Modernism, the Avant-garde, and High and Low Culture, edited by Sascha Bru, Laurence Nuijs, Benedikt Hjartarson, Peter Nicholls, Tania Ørum, and Hubert Berg, 425-445. Berlin: De Gruyter.

Hamilakis, Yannis. 2013. Archaeology and the Senses: Human Experience, Memory, and Affect. Cambridge and New York: Cambridge University Press.

Hebdidge, Dick. 1979. Subculture: The Meaning of Style. London and New York: Routledge. Hesmondhalgh, David. 2014. Why Music Matters. Malden: Wiley Blackwell.

Holst, Gail. 1979. Theodorakis: Myth and Politics in Modern Greek Music. Amsterdam: Hakkert. Holst-Warhart, Gail. 2007. "The Lion and the Jackal: Song as Protest during the Greek Dictatorship." Unpublished paper presented at the conference, "Balkan Literatures of Dissent," Brown University, 20 April.

Hutson, Scott R. 2000. “The Rave: Spiritual Healing in Modern Western Subcultures." Anthropological Quarterly 73 (1): 35-49.

Jackson, Phil. 2004. Inside Clubbing: Sensual Experiments in the Art of Being Human. Oxford and New York: Berg.

Kallimopoulou, Eleni. 2009. Paradosiaká: Music, Meaning and Identity in Modern Greece. Farnham: Ashgate. 


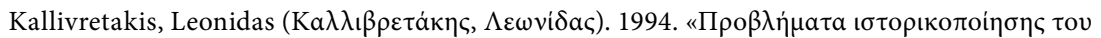

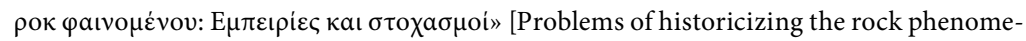
non: Experiences and thoughts]. Historica 11 (20): 157-174.

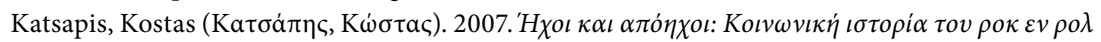
$\varphi \alpha \iota v o \mu \varepsilon \dot{v}$ ov $\sigma \tau \eta v E \lambda \lambda \dot{\alpha} \delta \alpha, 1956-1967$ [Sounds and echoes: A social history of the Rock 'n' roll phenomenon in Greece, 1956-1967]. Athens: Institute of Neohellenic Research.

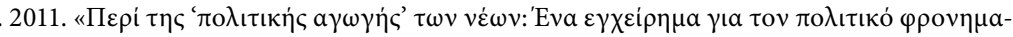

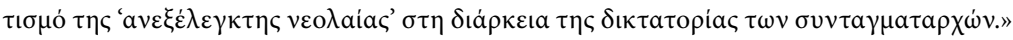
[On the "political education" of the young: An endeavor on the political bringing of the "uncontrollable youth" to its senses during the Colonels' dictatorship]. Ionios Logos 3: 203-220.

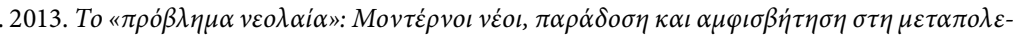
$\mu \iota \kappa \eta \dot{~} E \lambda \lambda \dot{\alpha} \delta \alpha$ [Youth as a "problem": Modern youth, tradition, and contestation in postwar Greece]. Athens: Aprovleptes.

Kornetis, Kostis. 2013. Children of the Dictatorship: Student Resistance, Cultural Politics, and the "Long 1960s" in Greece. New York and Oxford: Berghahn.

—. Forthcoming. "Neo Kyma." In Encyclopedia of Popular Music of the World, Part 3: Genres, edited by John Shepherd, David Horn, and Dave Laing. New York: Continuum.

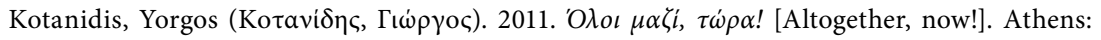
Kastaniotis.

Landsberg, Alison. 2010. "Waking the Deadwood of History: Listening, Language and the 'Aural Visceral." Rethinking History 14 (4): 531-549.

Lipsitz, George. 2001. Time Passages: Collective Memory and American Popular Culture. Minneapolis: University of Minnesota Press.

Malbon, Ben. 1998. "The Club, Clubbing: Consumption, Identity and the Spatial Practices of Every-Night Life." In Cool Places: Geographies of Youth Cultures, edited by Tracey Skelton and Gil Valentine, 267-287. London and New York: Routledge.

1999. Clubbing: Dancing, Ecstasy and Vitality. London and New York: Routledge.

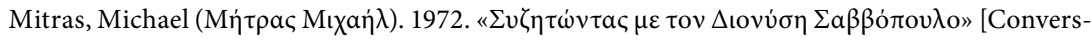

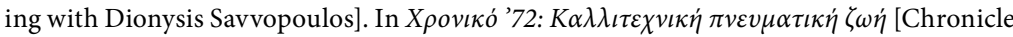
1972: Cultural life], vol. 3, 214-216.. Athens: Kallitehniko Pnevmatiko Kentro Ora.

Papadogiannis, Nikolaos. 2010. "Greek Communist Youth and the Politicisation of Leisure, 1974-1981.” PhD diss., Cambridge University.

2015. Militant Around the Clock? Left-Wing Youth Politics, Leisure, and Sexuality in Post-Dictatorship Greece, 1974-1981. New York: Berghahn.

Papaeti, Anna. Forthcoming. "Popular Music and the Colonels: Terror and Manipulation under the Military Dictatorship (1967-1974).” In Made in Greece: Studies in Greek Popular Music, edited by Dafni Tragaki. London and New York: Routledge.

Papanikolaou, Dimitris. 2007. Singing Poets Literature and Popular Music in France and Greece, 1945-1975. Oxford: Legenda.

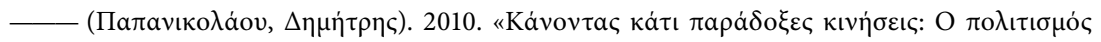

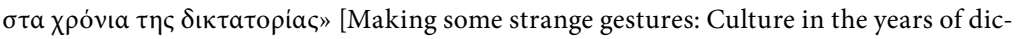

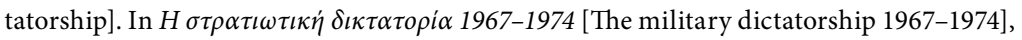

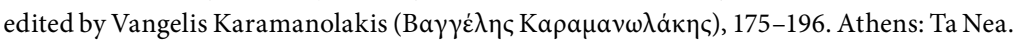

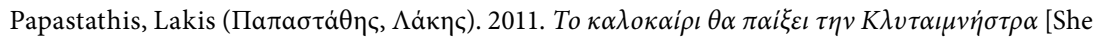
will play Clytemnestra in the summer]. Athens: Polis. 
Rill, Bryan. 2006. "Rave, Communitas, and Embodied Idealism." Music Therapy Today 7 (3): $648-661$.

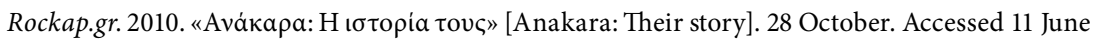

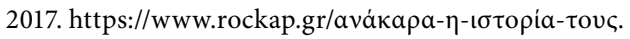

Roszak, Theodore. (1969) 1995. The Making of a Counter Culture: Reflections on the Technocratic Society and Its Youthful Opposition. Berkeley and Los Angeles: University of California Press.

St. John, Graham. 2008. "Trance Tribes and Dance Vibes: Victor Turner and Electronic Dance Music Culture." In Victor Turner and Contemporary Cultural Performance, edited by Graham St. John, 149-173. New York: Berghahn Books.

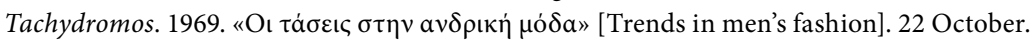

Théberge, Paul. 2001. "Plugged in': Technology and Popular Music." In The Cambridge Companion to Pop and Rock, edited by Simon Frith, Will Straw, and John Street, 3-26. Cambridge: Cambridge University Press.

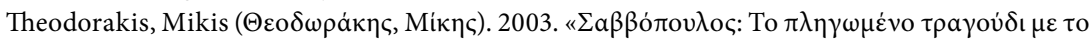

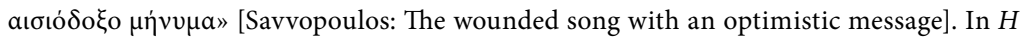
бovi $\mu \alpha$ [The sum up], edited by by Dionysis Savvopoulos, [135-139]. Athens: Ianos.

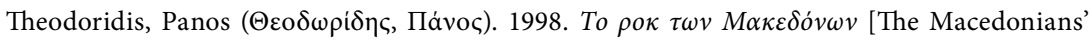
rock]. Salonica.

Thompson, E.P. 1966. The Making of the English Working Class. Random House: London.

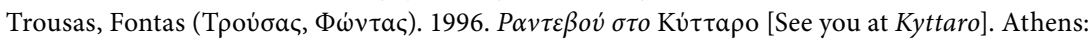
Delfini.

Van Dyck, Karen. 1998. Kassandra and the Censors: Greek Poetry since 1967. Ithaca: Cornell University Press.

Van Steen, Gonda. 2015. Stage of Emergency: Theater and Public Performance under the Greek Military Dictatorship, 1967-1974. Oxford: Oxford University Press.

Whiteley, Sheila. 1992. The Space Between the Notes: Rock and the Counterculture. London and New York: Routledge.

2012. "Countercultures: Music, Theory and Scenes." Volume! 9 (1): 6-16.

Zinn, Howard. 1980. A People's History of the United States, 1492-Present. New York and London: Routledge.

\section{INTERVIEWS}

Tasos Aronitis, June 2013

Stelios Elliniadis, June 2013

Stella Gadedi, June 2013

Nikos Kavoukidis, June 2013

Mariza Koch, June 2013

Dimitris and Olga Kourantis, June 2013

Lakis Papastathis, June 2013

Dionysis Savvopoulos, January 2004a

— July 2004b

Nikos and Liana Tsioulakis, June 2013 


\section{DISCOGRAPHY}

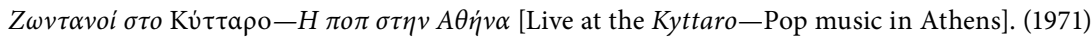
1996. Lyra.

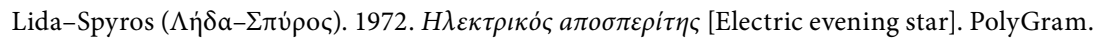
Savvopoulos, Dionysis ( $\Sigma \alpha \beta \beta$ ó

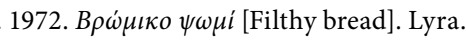

\section{FILMOGRAPHY}

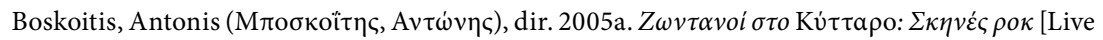
at the Kyttaro: Rock scenes]. Greece.

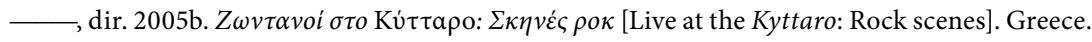
Promotional spot. Youtube. Accessed 11 June 2017. https://www.youtube.com/watch?v= -vjQ9oc4ntI.

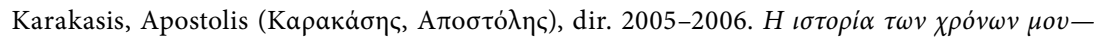

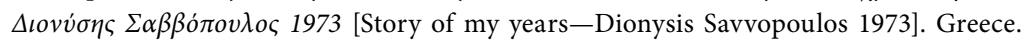
Accessed 28 February 2017. http://www.hprt-archives.gr/.

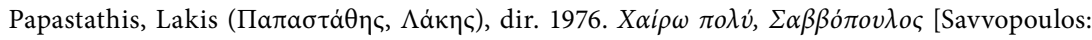
Pleased to meet you]. Greece.

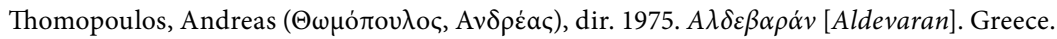

